\title{
RELEVANSI KURIKULUM HOSPITALITY POLITEKNIK PARIWISATA MAKASSAR TERHADAP RESTORAN DI SULAWESI SELATAN
}

\author{
Muhammad Arifin', Muh. Zainuddin Badollahi ${ }^{*}$ \\ Politeknik Pariwisata Makassar \\ *Email: muhammadzainuddinb@gmail.com
}

\begin{abstract}
This study aims to see where the relevance of the spatial management study program curriculum to restaurants in South Sulawesi specifically chooses 3 regencies/cities that have a $3 A$ visit level and tourism concept. By using quantitative descriptive. Based on research results found in the existing curriculum relevant to restaurants this can be used from the absorption of alumni who work in the hotel and restaurant sector as much as $98.94 \%$. Besides that the waiting time for alumni to get an average job is 3-6 months.
\end{abstract}

Keywords: relevance, curriculum, restaurants, politeknik pariwisata makassar

\section{PENDAHULUAN}

Perkembangan pariwisata membuka kesempatan bagi perempuan untuk menempati berbagai profesi, dapat dilihat dari keberadaan tenaga kerja perempuan dalam berbagai segmen industri pariwisata diantaranya: public relation, sales and marketing, house keeping, front office, ticketing, pramusaji dan pramugari (Badollahi \& Almy, 2019). Restoran dewasa ini mengalami perkembangan yang pesat, hal ini dikarenakan kegemaran masyarakat Sulawesi Selatan akan kuliner dan usaha pemerintah daerah Provinsi Sulawesi Selatan dalam mendorong sektor pariwisata, Peningkatan usaha dan rumah makan yang pesat, menjadikan persaingan bisnis rumah makan yang semakin kompetitif. Hal ini menyebabkan pengelola restoran berupaya keras dalam memilih strategi yang tepat untuk menarik konsumen sebanyak-banyaknya. Terkait dengan hal tersebut, maka perencanaan komunikasi pemasaran agar bisa sukses harus didasarkan pada suatu konsep komunikasi yang baik untuk bisa memenangkan hati konsumen, tidak hanya mengandalkan mutu atau kualitas produk yang bagus saja, tetapi juga harus mengkomunikasikan produk-produknya. Hal ini dikarenakan konsumen yang semakin cerdas dalam menentukan pilihan. 
Kurikulum memiliki kedudukan dan posisi yang sangat penting dalam proses pendidikan, kurikulum merupakan syarat mutlak dan bagian yang tak terpisahkan dari pendidikan itu sendiri. Melalui kurikulum dapat memberikan kompetensi-kompetensi yang dibutuhkan dunia kerja kepada mahasiswa, sehingga jika mahasiswa lulus mereka akan mudah terserap di dunia kerja yang sesuai kompetensi yang mereka dapat saat perguruan tinggi. Namun kompetensikompetensi yang diajarkan juga harus relevan dengan kompetensi yang dibutuhkan dunia kerja, karena setiap tempat usaha memiliki standar kompetensi yang sudah ditetapkan, sehingga relevansi kompetensi ini sangat penting bagi mahasiswa untuk terserapnya di dunia kerja.

Kurikulum berbasis kompetensi harus dikuasai mahasiswa setelah mereka menyelesaikan suatu program mata kuliah yang utama jelas kompetensi dalam bidang keahlian sendiri. Lulusan suatu prodi harus menguasai bidang keahliannya dan menguasai kompetensi yang diharapkan oleh prodi tersebut. Kompetensi bidang keahlian ini ditentukan, direncanakan dan dikembangkan oleh prodi. Prodi perlu menentukan kompetensi-kompetensi utama apa yang harus dikuasai mahasiswa Manajemen Tata Hidang, sehingga lulusannya dapat disebut sarjana yang berkualitas.

Standar Kompetensi lulusan merupakan kualifikasi para lulusan berupa pengetahuan dan keterampilan yang tercermin dalam cara bersikap dan berpikir. Standar kompetensi lulusan ini dijadikan kriteria bagi sekolah sebagai dasar pertimbangan kelulusan para peserta didiknya. Standar kompetensi Lulusan pada perguruan tinggi juga bertujuan untuk meningkatkan kecerdasan, pengetahuan, kepribadian, akhlak mulia, serta keterampilan agar peserta didik dapat hidup mandiri mengikuti pendidikan lebih lanjut.

Di dalam konteks restoran, faktor yang paling dipengaruhi oleh inisiatif atau pikiran karyawan secara berurutan adalah layanan, rasa makanan, dan lingkungan fisik. Selain itu ada pengaruh kepuasan melalui efek moderasi antara lain ada pada atribut utama restoran yaitu makanan, lingkungan, dan layanan (Zhang, 2013). Selanjutnya bahwa ada ilmuwan yang menyarankan terkait dengan pengalaman bersantap yang baru atau inovasi harus disediakan oleh restoran dengan menawarkan hidangan yang unik dan merevisi masakan secara teratur (Ramanathan, 2015). Selanjutnya bukan hanya kualitas makanan saja tetapi kualitas layanan juga diukur. Pandangan menarik diungkapkan bahwa 'kualitas layanan biasanya didasarkan pada penilaian pelanggan sehubungan dengan keunggulan keseluruhan atau keunggulan layanan yang diberikan (Qin, 2009). Jadi pada intinya kualitas layanan berpengaruh dan berkaitan dengan kepuasan pelanggan (Qin, 2009). Beberapa penelitian berdasarkan data The European Customer Satisfaction Index dan American Customer Satisfaction Index juga menganggap bahwa kualitas layanan merupakan salah satu hal yang mempengaruhi kepuasan pelanggan. 


\section{METODE PENELITIAN}

Pendekatan penelitian yang digunakan dalam penelitian ini adalah pendekatan kuantitatif yang lebih mementingkan metode pengukuran dan sampling karena menggunakan pendekatan deduktif yang menekankan prioritas yang mendetail pada koleksi data dan analisis (Hair et al, 2009). Penelitian ini dilakukan di kota Makassar, Kabupaten Bulukumba, Toraja dan Parepapare. Responden dari penelitian ini adalah alumni Program Studi Manajemen Tata Hidang.

\section{HASIL DAN PEMBAHASAN}

Keberhasilan dari Politeknik Pariwisata Makassar tidak hanya terukur dari pencapaian prestasi yang berupa nilai, namun jumlah mahasiswa yang terserap di dunia kerja juga menjadi salah satu indikator keberhasilan Politeknik Pariwisata Makassar. Saat ini pemerintah memiliki program dalam bidang pendidikan yaitu rasio jumlah lulusan Politeknik Pariwisata Makassar dan lulusan yang terserap didunia kerja bidang restoran. Program ini bertujuan untuk mengurangi jumlah pengangguran Politeknik Pariwisata Makassar yang notabene lulusan vokasi.

Lulusan yang siap kerja merupakan tanggung jawab Politeknik Pariwisata Makassar agar lulusannya kelak mudah memasuki dunia kerja yang relevan dengan bidang studi yang digelutinya, untuk itu diperlukan rancangan pendidikan yang tertuang di kurikulum Hospitality Politeknik Pariwisata Makassar karena kurikulum merupakan salah satu komponen penting dalam keberhasilan pendidikan, yang memberikan bekal berupa kompetensi kepada mahasiswa. yang relevan terhadap kompetensi yang dibutuhkan dunia kerja. Sesuai dengan Standar Nasional Pendidikan yang terdiri dari standar isi, proses, kompetensi lulusan, tenaga kependidikan, sarana dan prasarana, pengelolaan, pembiayaan, dan penilaian pendidikan yang harus ditingkatkan secara berencana dan berkala, sehingga mahasiswa sudah memiliki kompetensi sesuai dengan jurusan yang diambilnya.

\section{1) Gaji yang Diterima}

Gaji pada umumnya dibayarkan kepada karyawan tetap atau yang mempunyai jenjang jabatan tertentu setiap bulan (Mulyadi, 1993). Pada perusahaan atau instansi pembayaran kepada karyawan meliputi gaji, tunjangan keluarga, tunjangan transport dan lain - lain. namun yang terpenting bagi karyawan adalah penerimaan gaji, karena gaji adalah merupakan imbalan jasa yang dilakukan secara teratur dalam jumlah tertentu (Basuswasta, 2005). Dibawah ini tersaji data jumlah gaji yang diterima oleh alumni saat pertama kali bekerja. 
Tabel 1. Jumlah gaji lulusan prodi manajemen tata hidang saat pertama kerja (Sumber: Hasil Olah Data Kusioner)

\begin{tabular}{cccc}
\hline No. & \multicolumn{1}{c}{ Gaji } & Frekuensi & Persentase \\
\hline 1. & $1.000 .000-2.000 .000$ & 5 & $5.1 \%$ \\
2. & $2.000 .000-3.000 .000$ & 64 & $65.28 \%$ \\
3. & $3.000 .000-4.000 .000$ & 23 & $23.46 \%$ \\
4. & $\geq 5.000 .0000$ & 10 & $10.2 \%$ \\
\hline Total & & $\mathbf{1 0 2}$ & $\mathbf{1 0 0 \%}$ \\
\hline
\end{tabular}

Berdasarkan tabel diatas diketahui bahwa 64 responden atau sekitar (65.28\%) mengaku memiliki gaji Rp. 2.000.000-3.000.000, 23 responden (23.46\%) mengaku memiliki gaji Rp.3.000.000-4.000.000, 10 responden (10.2\%) mengaku memiliki pengahasilan diatas Rp. 5.000 .000 perbulan dan 5 responden $(5.1 \%)$ memiliki gaji Rp. 1.000.000-2.000.000.

\section{2) Lama Masa Tunggu}

Setelah lulus dari perguruan tinggi para alumni tentunya akan mencari pekerjaan baik itu yang sesuai dengan pendidikan yang didapatkan maupun yang tidak sesuai dengan pendidikan yang didapatkan pada perguruan tinggi. Saat memulai mencari pekerjaan, reponden memiliki cara yang berbeda untuk mencari informasi pekerjaan sehingga masa tunggu kerja pun berbeda-beda lamanya ada yang menunggu dalam kurung waktu 3(tiga) bulan, menunngu 3 sampai 6 bulan, menunggu 7 bulan sampai 1 tahun dan ada pula yang menunggu dari 1 tahun sampai dengan 2 tahun.

Lamanya waktu tunggu alumni dalam mendapatkan pekerjaan disebabkan karena adanya berbagai faktor yaitu diantaranya belum adanya lowongan pekerjaan yang cocok dengan minat alumni, dan ada pula alumni yang mengajukan lamaran pekerjaan namun belum juga dipanggil dan berbagai faktor lainnya.

Tabel 2. Lama masa tunggu kerja

(Sumber: Hasil Olah Data Kusioner)

\begin{tabular}{clcc}
\hline No. & Lama Tunggu Pekerjaan & Frekuensi & Persentase \\
\hline 1. & Kurang dari 3 bulan & 25 & $25.5 \%$ \\
2. & 3 bulan-6 bulan & 67 & $68.34 \%$ \\
3. & 7 bulan- 1 tahun & 7 & $7.14 \%$ \\
4. & 1-2 tahun & $\mathbf{1 0 2}$ & $3.06 \%$ \\
\hline Total & $\mathbf{1 0 0 \%}$ \\
\hline \multicolumn{4}{c}{ Dari tabel tersebut diatas, dapat diketahui bahwa waktu tunggu kerja } \\
alumni setelah lulus dari perguruan tinggi tentunya sangat bervariasi yaitu ada \\
yang langsung bekerja, kurang dari 3 bulan, 3 sampai 6 bulan, 7 sampai 1 tahun, \\
dan adapula antara 1 sampai 2 tahun baru mendapatkan pekerjaan. 67 responden
\end{tabular}


atau sekitar $68.34 \%$ mengatakan membutuhkan waktu 3 bulan-6 bulan untuk mendapatkan pekerjaan, 25 (25.5\%) alumni yang mendapatkan pekerjaan kurang dari bulan, 7 orang alumni atau sekitar $(7.14 \%)$ mendapatkan pekerjaan setelah 7 bulan sampai 1 tahun, dan 3 alumni atau sekitar (3.06\%) yang mendapatkan pekerjaan antara 1 sampai 2 tahun.

\section{3) Keterserapan Alumni di Dunia Kerja}

Dalam proses pendidikan selama mereka di Perguruan Tinggi kurikulum porsi mata kuliah pendidikan lebih banyak daripada pengetahuan manajemen tata hidang. Selama alumni belajar di perguruan tinggi, mereka telah mendapatkan berbagai macam materi atau mata kuliah yang nantinya dapat bermanfaat dalam dunia kerja. Akan tetapi faktanya ada mata kuliah yang tidak/kurang mendukung dalam dunia kerja. Untuk itu output Prodi Manajemen Tata Hidang diharapkan memiliki kompetensi yang menghasilkan lulusan yang berkomepeten di bidangnya.

Setelah para alumni lulus dan masuk dunia kerja tidak semua alumni bekerja di dunia perhotelan dan restoran. Tidak sedikit para lulusan yang bekerja justru tidak di bidang lain. Banyak lulusan yang tidak menjadi pramusaji tetapi di bidang yang tidak ada kaitannya dengan perhotelan dan restoran akan tetapi tetap tidak terlepas dalam bidang ekonomi. Relevan atau tidaknya kompetensi lulusan program studi Manajemen Tata Hidang dapat dilihat dari profil pekerjaan mereka yang meliputi jenis pekerjaan, jumlah jam kerja, jabatan, dan upah/gaji mereka.

Tabel 3. Keterserapan alumni di dunia kerja

\begin{tabular}{clcc}
\hline No. & \multicolumn{1}{c}{ Keterserapan Alumni } & Frekuensi & Persentase \\
\hline 1. & Bidang Perhotelan dan Restoran & 97 & $98.94 \%$ \\
2. & Non Perhotelan dan Restoran & 5 & $1.06 \%$ \\
\hline Total & & $\mathbf{1 0 2}$ & $\mathbf{1 0 0 \%}$ \\
\hline
\end{tabular}

Berdasarakan tabel diatas diketahui bahwa alumni Manajemen Tata Hidang 98.94\% bekerja pada sektor perhotelan dan restoran dan $1.06 \%$ bekerja pada sektor non perhotelan dan restoran. Hal ini mengeaskan bahwa alumni manajemen tata hidang bekerja sesuai dengan kompetensi yang dimiliki.

Keterserapan out put (alumni) di dunia kerja akan menjadi sumber kepercayaan masyarakat (sumber akuntabilitas sosial) terhadap universitas atau pun program studi. Apalagi jika setiap out put mampu menjadi perevisi dan pemberdaya nilai-nilai budaya lokal yang sesuai dengan perkembangan dan tuntutan global (Yana, 2002:2).

Dilihat dari data tracer studi pada tahun 2017 daya serap alumni Prodi Manajemen Tata Hidang pada restoran di hotel berbintang cukup tinggi. Hal ini dibuktikan dengan terserapnya alumni pada 20 hotel berbintang di Makassar 
antara lain: Zona Cafe \& Resto, Hotel Sahid Jaya Makassar, The Level, Star Buck Caffe Trans Studio, The Rindra Hotel, Gamara Hotel, Hotel Santika, Amaris Panakukang, Singgasana, Hotel Makassar Golden, Hotel Pantai Gapura, Swiss Belt Pantai Losari, Kenari Tower Hotel, Aswin Hotel \& Spa, Hotel Melia Makassar, Best Western Plus Makassar Beach, Miko Hotel and Convention Centre Makassar, Ibbis Style Makassar Sam Ratulangi Makassar, Hotel Novotel Makassar Grand Shaela, Golden Tulip Essential (Borang Akreditasi MTH, 2017:49)

Dari data diatas maka dapat disimpulkan bahwa lulusan Prodi Manajemen Tata Hidang terserap dengan baik dalam dunia kerja di bidang restoran. Itu artinya kurikulum yang diajarkan di bangku perkuliahan telah sesuai dengan kebutuhan industri.

Kurikulum memiliki kedudukan dan posisi yang sangat penting dalam proses pendidikan, kurikulum merupakan syarat mutlak dan bagian yang tak terpisahkan dari pendidikan itu sendiri. Melalui kurikulum, jurusan Hospitality Prodi Manajemen Tata Hidang Politeknik Pariwisata Makassar dapat memberikan kompetensi-kompetensi yang dibutuhkan dunia kerja kepada mahasiswa, sehingga jika mahasiswa lulus mereka akan mudah terserap di dunia kerja yang sesuai kompetensi yang mereka dapat saat di perguruan tinggi. Namun kompetensi-kompetensi yang diajarkan juga harus relevan dengan kompetensi yang dibutuhkan dunia kerja, karena setiap tempat usaha memiliki standar kompetensi yang sudah ditetapkan, sehingga relevansi kompetensi ini sangat penting bagi mahasiswa untuk terserapnya di dunia kerja.

\section{4) Relevansi Kepuasan Pelanggan}

Menurut Oka. A Yoeti (1999:1), jasa (service) merupakan suatu produk yang tidak nyata (intangible) dari hasil kegiatan timbal balik antara pemberi jasa (producer) dengan penerima jasa (costumer) melalui suatu atau beberapa aktivitas untuk memenuhi kebutuhan pelanggan. Aktivitas ini memungkin terjadinya penilaian atau tanggapan pelanggan terhadap kinerja karyawan yang secara tidak langsung berdampak pada penilaian tempat usaha tersebut, sehingga pelayan atau karyawan harus memiliki keahlian yang dapat memberikan rasa puas terhadap pelanggan.

Tabel 4. Relevansi Kepuasan Pelanggan dari keahlian yang didiapatkan mahasiswa saat kuliah

\begin{tabular}{lccc}
\hline \multicolumn{1}{c}{ PERNYATAAN } & $\begin{array}{c}\text { Responden } \\
(\mathbf{N})\end{array}$ & $\begin{array}{c}\text { Hasil } \\
(\mathbf{\%})\end{array}$ & Kriteria \\
\hline $\begin{array}{l}\text { Keamanan kendaraan yang diparkir } \\
\text { Kemudahan dalam memperoleh } \\
\text { pelayanan }\end{array}$ & 102 & 3.81 & Cukup relevan \\
\hline
\end{tabular}




\begin{tabular}{|c|c|c|c|}
\hline Kemudahan dalam pembayaran & 102 & 3.76 & Cukup relevan \\
\hline $\begin{array}{l}\text { Kemudahan dalam memperoleh } \\
\text { tempat duduk }\end{array}$ & 102 & 3.99 & Cukup relevan \\
\hline $\begin{array}{l}\text { Lokasi restoran yang mudah } \\
\text { dijangkau }\end{array}$ & 102 & 4. 01 & Relevan \\
\hline Kebersihan makanan dan minuman & 102 & 3.97 & Cukup relevan \\
\hline $\begin{array}{l}\text { Kesesuaian harga dengan kualitas } \\
\text { makanan }\end{array}$ & 102 & 3.81 & Cukup relevan \\
\hline Kelezatan makanan dan minuman & 102 & 3.92 & Cukup relevan \\
\hline $\begin{array}{l}\text { Pemberian diskon dalam pembelian } \\
\text { tertentu }\end{array}$ & 102 & 3.39 & Cukup relevan \\
\hline $\begin{array}{l}\text { Kenyamanan } \\
\text { restoran }\end{array}$ & 102 & 3.33 & Cukup relevan \\
\hline $\begin{array}{l}\text { Kesiapan karyawan dalam melayani } \\
\text { konsumen }\end{array}$ & 102 & 3.55 & Cukup relevan \\
\hline $\begin{array}{l}\text { Informasi mengenai menu yang } \\
\text { disajikan }\end{array}$ & 102 & 3.62 & Cukup relevan \\
\hline $\begin{array}{l}\text { Perhatian dengan keinginan } \\
\text { pelanggan }\end{array}$ & 102 & 3.53 & Cukup relevan \\
\hline Jumlah Total & 102 & 56.64 & \\
\hline Rerata & 102 & 4. 31 & \\
\hline
\end{tabular}

Dari tabel diatas dapat diketahui bahwa relevansi kepuasaan pelanggan paling tinggi adalah lokasi restoran yang mudah dijangkau sebesar $4.01 \%$, Kemudahan dalam memperoleh tempat duduk sebesar $3.99 \%$, kemudahan dalam memperoleh pelayanan sebesar $3.97 \%$, kebersihanan makanan dan minuman sebesar $3.97 \%$, kelezatan makanan dan inuman sebesar $3.92 \%$, kesuaian harga dengan kualitas makanan sebesar $3.81 \%$, keamanan kendaraan yang diparkir sebesar $3.81 \%$, kemudahan dalam pembayaran sebesar $3.76 \%$, informasi mengenai menu yang disajikan sebesar $3.62 \%$, kesiapan karyawan dalam melayani konsumen sebesar $3.55 \%$, perhatian dengan keinginan pelanggan sebesar $3.53 \%$ dan terendah adalah kenyamaan suasana dalam restoran sebesar $3.33 \%$. Berdasarkan tabel diatas rata-rata relevansi kepuasan pelanggan yang dibutuhkan dunia kerja termasuk kategori sangat relevan yaitu $4.31 \%$.

Nilai kepuasan yang belum terpenuhi tersebut dapat dikarenakan perbedaan tingkat kepentingan dan kinerja terhadap atribut-atribut yang dinilai oleh masing-masing konsumen karena setiap konsumen memiliki penilaian terhadap kepentingan dan kinerja yang berbeda-beda. Dengan demikian, pihak restoran perlu mengetahui tingkat kepentingan dan kinerja dari atribut-atribut restoran untuk perbaikan secara mendalam. 
Konsumen memiliki kepentingan yang tinggi terhadap lokasi restoran karena konsumen menginginkan restoran yang mudah dijangkau oleh kendaraan apapun. Letak restoran yang dapat dilalui oleh kendaraan baik kendaraan roda empat atau dua, sehingga kinerja mempermudah pelanggan dinilai baik oleh konsumen serta nilai kinerja rata-rata berada di atas kinerja restoran.

Kebersihan restoran secara umum telah baik. Hal tersebut menggambarkan restoran telah memberikan kinerja yang melampaui kinerja rata-rata restoran. Meskipun beberapa konsumen menyatakan terkadang ada nyamukyang mengganggu saat konsumen menikmati kuliner restoran. Namun, secara keseluruhan konsumen menilai kondisi kebersihan restoran yakni tidak ada sampah di meja, kursi, lantai, serta tempat pemilihan ikan serta fasilitas toilet dalam keadaan bersih, tetapi terkadang lantai berdebu. Pihak restoran harus mempertahankan kinerja kebersihan restoran nilainya penting di mata konsumen. Pihak restoran harus senantiasa membersihkan fasilitas umum yang ada di restoran meskipun fasilitas tersebut jarang dimanfaatkan oleh konsumen. selain fasilitas umum restoran, ruangan makan restoran harus dibersihkan dari kotoran dan debu sebelum konsumen menggunakannya, termasuk menjaga kesehatan kolam dengan melakukan fogging secara berkala.

Harga makanan dan minuman yang dimaksud adalah sejauh mana harga makanan dan minuman yang ditawarkan restoran tertentu sesuai dengan pelayanan, kualitas, dan rasa yang diberikan. Konsumen restoran merasakan harga yang ditawarkan restoran kurang sesuai dengan pelayanan, kualitas, dan rasa dari restoran tersebut, sehingga penilaian kinerja konsumen rendah terhadap atribut ini, bahkan lebih rendah dari pada kinerja rata-rata restoran. Hal tersebut mengindikasikan kalau kinerja atribut ini belum dapat dikatakan baik.

Menurut konsumen, apabila dibandingkan dengan restoran lainnya di luar Sulawesi Selatan, harga makanan dan minuman restoran Sulawesi Selatan cenderung lebih mahal. Hal tersebut wajar, karena konsumen tidak memperhitungkan bahan baku yang digunakan oleh restoran terutama yang menggunakan bahan baku seafood. Namun, untuk memfasilitasi konsumen yang tidak puas terhadap atribut ini, maka restoran harus memperhatikan kisaran ratarata kuliner seafood. Selain itu, restoran dapat memberikan diskon khusus, paket promosi, atau kartu member diskon kepada konsumen.

Hal lain yang dikeluhkan adalah konsep penyajian terutama makanan hyang bebahan baku seafood, waktu lama untuk mengolah bahan baku seafood hidup menjadi makanan siap santap. Namun, konsumen memiliki kepentingan yang tinggi terhadap kecepatan waktu penyajian, karena aktivitas konsumen beragam. Hal tersebut tidak sebanding dengan kinerja restoran yang belum dapat dikatakan baik oleh konsumen karena nilai kinerja atribut lebih rendah dibandingkan nilai kinerja rata-rata restoran. Menurut konsumen, selain pesanan memerlukan waktu cukup lama untuk diantarkan ke meja konsumen, menu juga 
tidak diantar secara bersamaan, sehingga konsumen tidak dapat menyantap seluruh menu pesanan secara bersamaan.

Sebagian besar konsumen mengatasi lama waktu pesanan dengan berbincang-bincang bersama rekan atau kerabat, menikmati pemandangan sekitar. Pihak restoran tetap harus memperbaiki dan meningkatkan kinerja atribut kecepatan penyajian dengan mempercepat proses pemasakan melalui pembagian tugas koki. Selain itu, proses pemasakan juga harus harus bersamaan, sehingga pesanan dapat dihidangkan secara bersamaan. Dengan demikian, kinerja konsumen terhadap atribut kecepatan penyajian dapat ditingkatkan.

Tabel 5. Relevansi kualitas pelayanan terhadap pelanggan

\begin{tabular}{|c|c|c|c|}
\hline PERNYATAAN & $\begin{array}{l}\text { Responden } \\
\text { (N) }\end{array}$ & $\begin{array}{l}\text { Persentase } \\
(\%)\end{array}$ & Ket. \\
\hline Kecepatan makanan yang dipesan & 102 & 3.67 & $\begin{array}{l}\text { Cukup } \\
\text { relevan }\end{array}$ \\
\hline Ketepatan makanan yang dipesan & 102 & 4. 37 & Relevan \\
\hline $\begin{array}{l}\text { Fasilitas pendukung cukup } \\
\text { menunjang (TV, musik) }\end{array}$ & 102 & 4. 12 & Relevan \\
\hline Tempat duduk yang tersedia & 102 & 3.97 & Cukup relevan \\
\hline $\begin{array}{l}\text { Kecepatan pelayanan dalam } \\
\text { melayani }\end{array}$ & 102 & 3.92 & Cukup relevan \\
\hline $\begin{array}{l}\text { Sikap ramah karyawan terhadap } \\
\text { konsumen }\end{array}$ & 102 & 3. 76 & Cukup relevan \\
\hline $\begin{array}{l}\text { Karyawan cepat tanggap dalam } \\
\text { menangani keluhan }\end{array}$ & 102 & 3. 33 & Cukup relevan \\
\hline $\begin{array}{l}\text { Cepat tanggap dalam membersihkan } \\
\text { meja konsumen }\end{array}$ & 102 & 3.56 & Cukup relevan \\
\hline Kebersihan dalam ruangan restoran & 102 & 3.56 & Cukup relevan \\
\hline $\begin{array}{l}\text { Ketepatan penataan tata letak yang } \\
\text { menarik }\end{array}$ & 102 & 3.47 & Cukup relevan \\
\hline Kerapihan penampilan karyawan & 102 & 3.45 & Cukup relevan \\
\hline $\begin{array}{l}\text { Keindahan pada Interior restoran } \\
\text { ini }\end{array}$ & 102 & 3.27 & Cukup relevan \\
\hline $\begin{array}{l}\text { Perasaan aman ketika berada di } \\
\text { dalam restoran }\end{array}$ & 102 & 3. 49 & Cukup relevan \\
\hline $\begin{array}{l}\text { Jaminan kenyamanan yang } \\
\text { diberikan restoran }\end{array}$ & 102 & 3.84 & Cukup relevan \\
\hline $\begin{array}{l}\text { Restoran Tidak Menggunakan } \\
\text { Bahan Makanan berbahaya bagi } \\
\text { Kesehatan Para Konsumen }\end{array}$ & 102 & 3.64 & Cukup relevan \\
\hline Mengantarkan tamu ke tempat & 102 & 3.82 & Cukup relevan \\
\hline
\end{tabular}




\begin{tabular}{lccc}
\hline $\begin{array}{l}\text { duduk } \\
\text { Mengucapkan salam kepada } \\
\text { konsumen }\end{array}$ & 102 & 3.64 & Cukup relevan \\
$\begin{array}{l}\text { Perhatian kepada setiap kebutuhan } \\
\text { konsumen }\end{array}$ & 102 & 3.53 & Cukup relevan \\
$\begin{array}{l}\text { Pelayanan yang diberikan kepada } \\
\text { semua pelanggan tanpa memandang }\end{array}$ & 102 & 3.58 & Cukup relevan \\
$\begin{array}{l}\text { Status Sosial } \\
\begin{array}{l}\text { Senantiasa berada di sekitar } \\
\text { konsumen }\end{array}\end{array}$ & 102 & 3.71 & Cukup relevan \\
$\begin{array}{l}\text { Mengenal pelanggan dengan baik } \\
\text { Jumlah } \\
\text { Rerata }\end{array}$ & 102 & 3.87 & $\begin{array}{c}\text { Cukup relevan } \\
\mathbf{7 8 . 5 7}\end{array}$ \\
\hline
\end{tabular}

Dari tabel diatas dapat diketahui bahwa relevansi kualitas pelayanan paling tinggi adalah kecepatan makanan yang dipesan sebesar $4.37 \%$, fasilitas cukup menunjang (TV dan musik) sebesar $4.12 \%$, tempat duduk yang tersedia sebesar $3.97 \%$, kecepatan pelayanan dalam melayani sebesar $3.92 \%$, jaminan kenyamanan yang diberikan restoran sebesar $3.84 \%$, mengenal pelanggan dengan baik seebsar 3.87\%, mengantarakan tamu ke tempat duduk sebesar 3.82\%, sikap ramah karyawan terhadap konsumen sebesar 3.76\%, senantiasa berada disekitar konsumen sebesar 3.71\%, kecepatan makanan yang diproses sebesar 3.67\%, restoran tidak menggunakan bahan makanan yang tidak berbahaya sebesar $3.64 \%$, mengucapkan salam pada konsumen $3.64 \%$, pelayanan yang diberikan kepada semua pelanggan tanpa memandang status sosial sebesar $3.58 \%$, cepat tanggap dalam membersihkan meja konsumen sebesar $3.56 \%$, kebersihan dalam ruangan restoran sebesar $3.56 \%$, perhatian kepada setiap kebutuhan konsumen sebesar $3.53 \%$, perasaan aman ketika berada didalam restoran sebesar $3.49 \%$, ketepatan penataan tata letak yang menarik sebesar $3.47 \%$, kerapihan penampilan karyawan sebesar $3.45 \%$, karyawan cepat tanggap dalam menangani kenutuhan sebesar $3.33 \%$ dan terendah adalah keindahan pada interior sebesar $3.33 \%$. Berdasarkan tabel diatas rata-rata relevansi kualitas pelayana yang diterima oleh pelanggan termasuk kategori sangat relevan yaitu $3.74 \%$.

\section{Relevansi Kompetensi dan Kurikulum Hospitality}

Kompetensi merupakan kinerja (performance) yang rasioal yang secara memuaskan memenuhi tujuan serta sesuai dengan kondisi yang diharapkan. Serdamayanti (2004: 43) mengemukakan beberapa pengertian kompetensi yaitu kemampuan atau kemauan untuk melakukan pekerjaan, kemampuan dasar dan kualitas kinerja yang diperlukan untuk mengerjakan pekerjaan dengan baik.

Kurikulum Hospitality Politeknik Pariwisata Makassar juga fleksibel yang memberikan kebebasan pada mahasiswa untuk memilih program pendidikan 
dalam kelompok peminatan. Prinsip kurikulum pendidikan seumur hidup yang harus menanamkan nilai dan norma bagi mahasiswa pihak prodi Hospitality Politeknik Pariwisata Makassar sudah memberikan fasilitas tersebut dengan adanya mata kuliah agama dan budi pekerti.

Pengembangan kurikulum selalu perlu dicermati, karena sifatnya selalu dinamis dan pasti akanberkembang seiring dengan perkembangan IPTEK dan tuntutan masyarakat. Para ahli kurikulum berpendapat bahwa kurikulum adalah alat istrumen untuk mencapai tujuan pendidikan dan pembelajaran yang ditetapkan, akan tetapi kurikulum bukan satu-satunya tujuan akhir dari pendidikan itu sendiri.

Menurut penuturan salah seorang responden;

"Saat ini banyak lulusan yang bekerja tidak sesuai dengan latar belakang pendidikannya. Ada yang lulusan otomotif, kerja di hotel atau lulusan hospitality, kerja di bank. Nah, itu yang akan kami rubah, bagaimana lulusan dari lembaga pendidikan vokasi ini bisa langsung bekerja sesuai latar belakangnya".

Dapat dijumpai lulusan vokasi bekerja tidak sesuai dengan latar belakang pendidikannya karena kompetensi lulusan yang didapat di perguruan tinggi tidak dibutuhkan pihak industri.

Hasil studi pelacakan ini memperlihatkan bahwa lulusan Program Studi Manajemen Tata Hidang memiliki kelemahan utama dalam hal kemampuan adaptasi dengan lingkungan pekerjaan dan penguasaan bahasa Inggris yang masih perlu ditingkatkan, sedangkan hal lainnya relatif baik, yaitu profesionalisme, kedisiplinan. Keahlian/kemampuan yang menjadi keunggulan lulusan PS. Manajemen Tata Hidang antara lain sebagai berikut:

1. Mampu menyelenggarakan/merencanakan dan menyajikan makanan

2. Mampu mengembangkan inovasi penyajian makanan

3. Mampu mendesain dan menata hidangan

4. Mampu mengelola Restoran dan Bar pada hotel, Restoran, Katering, Barista, serta industri katering lainnya

5. Mampu memimpin organisasi pada bidang penyajian makanan, dan minuman

6. Mampu menerapkan pada bidang penyajian makanan dan minuman

7. Mampu membuka lapangan kerja dan usaha di bidang penyajian makanan dan minuman

8. Mampu menjadi asisten pengajar/pengawas praktik pada bidang Manajemen Tata Hidang 
Tabel 6. Relevansi kompetensi dan kesesuaian kurikulum

\begin{tabular}{|c|c|c|c|}
\hline PERNYATAAN & $\begin{array}{l}\text { Responden } \\
\text { (N) }\end{array}$ & $\begin{array}{c}\text { Persentase } \\
(\%)\end{array}$ & Ket. \\
\hline Kesesuaian Kurikulum dan Dunia Kerja & 102 & 4.57 & Relevan \\
\hline $\begin{array}{l}\text { Kesesuaian antara keahlian dosen } \\
\text { dengan mata kuliah yang diajarkan }\end{array}$ & 102 & 4. 39 & Relevan \\
\hline $\begin{array}{l}\text { mata kuliah praktik menggunakan } \\
\text { dasar-dasar pendidikan dan pengajaran } \\
\text { dalam mengajarnya }\end{array}$ & 102 & 4. 28 & Relevan \\
\hline hubungan dosen dan mahasiswa & 102 & 4. 22 & Relevan \\
\hline $\begin{array}{l}\text { Fasilitas/sarana dan prasarana yang } \\
\text { mendukung pembelajaran praktek }\end{array}$ & 102 & 4. 49 & Relevan \\
\hline Kegiatan pengajaran dan pelatihan & 102 & 4. 44 & Relevan \\
\hline Metode Kuliah & 102 & 4. 15 & Relevan \\
\hline Bahan Kuliah & 102 & 4. 35 & Relevan \\
\hline Praktek Kuliah & 102 & 4. 19 & Relevan \\
\hline Sumber Daya Pengajar & 102 & 4. 19 & Relevan \\
\hline Materi pelatihan yang mengarah kepada & 102 & 4.21 & Relevan \\
\hline keterpaduan kesepakatan terhadap & & & \\
\hline kebutuhan pasar dan persaingan & & & \\
\hline Manajemen Sumber Daya Manusia & 102 & 4. 20 & Relevan \\
\hline Fasilitas Fisik Pelatihan & 102 & 4. 19 & Relevan \\
\hline Penyempurnaan berbagai standarisasi & 102 & 4. 38 & Relevan \\
\hline $\begin{array}{l}\text { Kegiatan pengajaran dan pelatihan } \\
\text { mengarah kepada penguatan jati diri } \\
\text { bangsa, sekaligus pengembangan konsep } \\
\text { multikultur seperti penguasaan bahasa } \\
\text { internasional. }\end{array}$ & 102 & 4. 29 & Relevan \\
\hline Persiapan Peralatan & 102 & 4. 13 & Relevan \\
\hline Bumbu dan bahan & 102 & 4. 12 & Relevan \\
\hline Teknik pengolahan makanan & 102 & 4. 19 & Relevan \\
\hline $\begin{array}{l}\text { Terminologi /istilah dan prosedur } \\
\text { pengolahan makanan }\end{array}$ & 102 & 4. 13 & Relevan \\
\hline Kriteria dan pemorsian makanan & 102 & 4.47 & Relevan \\
\hline Keamanan pangan & 102 & 4.21 & Relevan \\
\hline Bekerja sama & 102 & 4. 12 & Relevan \\
\hline Dispilin & 102 & 4. 19 & Relevan \\
\hline Bertanggungjawab & 102 & 4. 21 & Relevan \\
\hline Kesediaaan diberi saran dan kritikan & 102 & 4. 12 & Relevan \\
\hline Berjiwa inisiatif, kreatif dan menerima & 102 & 4. 19 & Relevan \\
\hline
\end{tabular}




\begin{tabular}{|c|c|c|c|}
\hline \multicolumn{4}{|l|}{ kekurangan orang lain } \\
\hline $\begin{array}{l}\text { Mengolah menu hidangan daging, } \\
\text { ungags seafood dan sayuran }\end{array}$ & 102 & 4. 21 & Relevan \\
\hline $\begin{array}{l}\text { Mengolah menu hidangan nasi, dan } \\
\text { pasta }\end{array}$ & 102 & 4. 24 & Relevan \\
\hline $\begin{array}{l}\text { Mengolah menu hidangan Appetizer, } \\
\text { main course dan Dessert }\end{array}$ & 102 & 4. 39 & Relevan \\
\hline Mengolah kaldu dan saos & 102 & 4. 38 & Relevan \\
\hline Membuat garnish dan salad & 102 & 4. 24 & Relevan \\
\hline Menyajikan masakan & 102 & 4. 31 & Relevan \\
\hline Mengolah masakan sesuai standar & 102 & 4. 33 & Relevan \\
\hline $\begin{array}{l}\text { Melaksanakan kebersihan dan kemanan } \\
\text { pangan }\end{array}$ & 102 & 4. 23 & Relevan \\
\hline
\end{tabular}

Berdasarakan tabel diatas maka diketahui bahwa relevansi kurikulum dan kompetensi yang tertinggi adalah kesesuaian kurikulum dengan dunia kerja sebesar $4.57 \%$, diikuti dengan fasilitas sarana dan prasarana yang mendukung pembelajaran praktek sebesar $4.49 \%$, kriterian dan pemorsian makanana sebesar $4.47 \%$, kegiatan pengajaran dan pelatihan sebesar $4.44 \%$, kesesuaian antara keahlian dosen dengan mata kuliah yang diajarakan sebesar $4.39 \%$, mengolah menu hidangan appetizier, main corse dan dessert sebesar $4.39 \%$, penyempurnaan berbagai standarisasi sebesar 4.38\%, mengolah kaldu dan saos sebesar $4.38 \%$, bahan kuliah sebesae $4.35 \%$, mengolah masakan sesuai standar sebesar $4.33 \%$, menyajikan makanan sebesar $4.31 \%$ kegiatan pengajaran dan pelatihan mengarah kepada penguatan jati diri bangsa sekaligus pengembangan konsep multikultur seperti penguasaan bahasa internasional sebesar $4.29 \%$, mata kuliah praktek yang menggunakan dasar-dasar pendidikan dan pengajaran dalam mengajar sebesar $4.28 \%$, mengolah menu hidangan nasi dan pasta sebesar $4.24 \%$, membuat garnis dan salad seebesar $4.24 \%$, melakukan kebersihan dan keamanan pangan sebesar $4.23 \%$, hubungan dosen dan mahasiswa sebesar $4.22 \%$, materi pengalihan yang mengarah kepada keterpaduan kesepakatan terhadap kebutuhan pasar dan persaingan sebesar $4.21 \%$, keamanan pangan sebesar $4.21 \%$, bertanggungjawab sebesar $4.21 \%$, mengolah menu hidangan daging, unggar, seafod dan sayuran sebesar $4.21 \%$, manajemen sumberdaya manusia sebesar $4.20 \%$, fasilitas fisik dan pelatihan sebesar $4.19 \%$, berjiwa inisiatif, kreatif dan menerima kekurangan orang lain sebesar $4.19 \%$, praktek kuliah sebesar $4.19 \%$, Sumberdaya Pengajar sebesar $4.19 \%$, teknik pengolahan makanan sebesar $4.19 \%$, disiplin sebesar $4.19 \%$, metode kuliah sebesar $4.15 \%$, persiapan peralatan sebesar $4.13 \%$, teknologi/ istilahdan prosedur pengolahan makanan sebesar $4.13 \%$, dan relevansi kurikulum dan kompetnsi yang terendah terdapat pada penguasaan bumbu dan bahan sebesar 
$4.12 \%$, bekerja sama sebesar $4.12 \%$, kesediaan diberi saran dan kritikan sebesar $4.12 \%$. Berdasarkan hasil rata-rata disetiap kompetesi diatas, dapat disimpulkan kompetensi yang diajarkan di Prodi Hospitality Politeknik Pariwisata termasuk kategori sangat relevan. Berikut tabel rata-rata setiap kompetensi:

Para lulusan Politeknik Pariwisata Makassar yang telah bekerja juga menyatakan bahwa keterampilan yang dibutuhkan oleh lapangan kerjanya relevan dengan pelajaran yang diperolehnya di Politeknik Pariwisata Makassar. Fakta ini menunjukkan bahwa lapangan kerja bagi lulusan Politeknik Pariwisata Makassar sebagian besar sesuai dengan apa yang diperoleh selama menempuh pendidikan di Politeknik Pariwisata Makassar. Temuan ini sejalan dengan apa yang dikehendaki oleh dunia industri, yaitu produktivitas dan efisiensi kerja yang tinggi, langsung berdampak pada dunia pendidikan yang secara aktual semakin dijadikan instrumen sosialisasi dan kaderisasi demi proses anonim dunia industri tersebut.

Menurut responden, ada beberapa aspek penting yang menyebabkan para alumni direkrut oleh Instansi/Perusahaan. Aspek-aspek penting tersebut adalah kemampuan berbahasa Inggris, kepribadian, dan penampilan serta kemampuan komputer.

Mata Kuliah yang Mendukung Pekerjaan; Menurut responden, matakuliah pendukung pekerjaan di lapangan di antaranya matakuliah yang berkaitan dengan pendidikan dan pengajaran dan mata kuliah bidang studi. Namun demikian ada beberapa mata kuliah bidang studi yang paling dianggap mendukung pekerjaan alumni, yaitu: (1) operasional restoran 1, (2) operasional restoran 2, (3) operasional restoran 3, (4) operasional bar 1, (5) operasional bar 2, (6) penanganan peralatan, (7) pengetahuan menu, (8) pengetahuan tata boga, (9) supervise tata hidang, (10) barista artscape, (11) mixiology.

Mata kuliah yang berkaitan dengan operasional restoran yang dianggap paling mendukung, yaitu: (1) perencanaan desain menu, (2) kekasiran restoran dan bar, (3) manajemen restoran dan bar, (4) Pengendalian biaya hospitality 1, (5) pengendalian hospitality 2, (6) Higiene, sanitasi dan keselamatan kerja. Matakuliah yang berkaitan dengan teori tari yang dirasakan besar dukungannya, yaitu: (1) pengantara pariwisata hospitality, (2) psikologi pelayanan, (3) kewirausahaan, (4) bisnis hospitality, (5) manajemen sumber daya, (6) dasar-dasar akuntasni hospitality, (7) pemahaman lintas budaya, (8) pemasaran hospitality, (9) statistika hotel. Matakuliah yang berkaitan denagn praktek yaitu: (1) aplikasi komputer, (2) bahasa asing, (3) bahasa inggris, (4) metode penulisan laporan

Daya serap alumni prodi Manajemen Tata hidang sangat dibutuhkan di dunia kerja. Dampak yang dapat dirasakan dengan dilakukannya sejumlah upaya ini adalah lulusan memiliki masa studi tepat waktu (rata-rata 36 bulan), rata-rata nilai IPK yang relatif tinggi $(3,62)$, dan waktu yang dibutuhkan untuk mendapat 
pekerjaan pertama juga relatif singkat (3 bulan), bahkan sebahagian besar diantaranya telah bekerja pada semester akhir.

Dari hasil analisis data diperoleh $65 \%$ mengatakan bahwa mata kuliah yang ada di Prodi Manajemen Tata Hidang relevan dengan dunia kerja lulusan di Restoran. Sementara itu 32\% mengatakan cukup relevan, 2\% mengatakan kurang relevan, dan 1\% mengatakan tidak relevan. Pernyataan relevan dan cukup relevan dari data yang diperoleh sebagian besar dikatakan oleh lulusan yang bekerja. Sedangkan yang mengatakan kurang relevan adalah lulusan yang juga bekerja di luar bidang hospitality dan alumni yang tidak/belum bekerja.

Kriteria sangat relevan untuk jangka panjang materi yang diajarkan harus tetap disesuaikan dengan kebutuhan hotel. Hal ini terkait dengan perkembangan kurikulum yang belum bisa mengimbangi perkembangan teknologi di perusahaan yang berubah sangat cepat. Karena perkembangan teknologi di perusahaan merupakan tuntutan permintaan konsumen yang perkembangannya dari hari ke hari selalu menginginkan yang lebih baik. Tentu saja hal ini sangat sulit diikuti oleh Prodi Manajemen Tata Hidang Politeknik Pariwisata Makassar, karena kurikulum di Politeknik Pariwisata Makassar dirancang untuk masa 5 tahun.

Dengan kriteri sangat relevan kurikulum Prodi Manajemen Tata Hidang Politeknik Pariwisata Makassar perlu diimbangi dengan kualitas dosen dan staf pengajar, peralatan dan sarana supaya kurikulum tersebut tidak hanya seperti apa yang tertulis dalam buku kurikulum tetapi bisa diimplementasikan dengan baik. Keberhasilan pelatihan pemagangan perhotelan juga tidak lepas dari peranan dosen yang mengajarkan ketrampilan-ketrampilan bidang perhotelan.

Relevansi kompetensi lulusan dengan pekerjaan yang akan di geluti sangatlah penting hal ini akan membantu lulusan lebih cepat dalam memperoleh pekerjaan dan membangun karir nya di tempat dia bekerja. Relevansi Menurut Rhiza S. Sadjad (2002) :"Relevansi merupakan komponen yang terpenting karena merupakan faktor yang menentukan eksistensi dari lembaga pendidikan yang bersangkutan". Suatu perguruan tinggi dapat dikatakan dikatakan sebagai universitas yang baik dan dapat diakui eksistensinya baik oleh masyarakat maupun perusahaan atau dunia usaha jika seluruhnya atau sebagian besar lulusannya dapat dengan cepat diserap oleh lapangan kerjayang sesuai dengan bidang dan peringkat stratanya, baik di tingkat lokal, nasional maupun internasional. Menurut Brojonegoro dalam Tritjahjo (2005: 57) "Kebijakan program untuk meningkatkan mutu dan relevansi pendidikan meliputi empat aspek yaitu: kurikulum, tenaga kependidikan, sarana pendidikan dan kepemimpinan satuan pendidikan"

\section{Analisis Swot}

\section{1) Analisis Visi}

1. Kekuataan Dari sisi Visi Prodi Manajemen Tata Hidang dirumuskan secara realistik dan fleksibel yang didasarkan pada pengkajian untuk 
kurun waktu tertentu sekarang dan dimasa yang akan datang, yang disesuaikan dengan perkembangan ilmu dan teknologi, serta kenyataan tuntutan kompetensi yang yang harus dimiliki oleh para lulusan untuk menghadapi persaingan global, pada masa datang dalam perkembangan dunia kuliner masyarakat nasional dan global.

2. Kelemahan sebagian besar mahasiswa belum sepenuhnya dapat mengimplementasikan visi program studi.

3. Peluang: Prodi Manajemen Tata Hidang memiliki potensi dan kemampuan untuk berperan secara efektif dalam pembangunan khususnya dalam bidang kepariwisataan sebagai barista dan mixiology.

4. Tantangan: Banyaknya sekolah Pariwisata di Makassar yang mencetak banyak lulusan menjadi tantangan bagi alumni Manajemen tata Hidang dalam mencari pekerjaan.

\section{2) Analisis Misi}

1. Kekuatan: Prodi Manajemen Tata Hidang diuraikan secara jelas dan lengkap sesuai dengan upaya yang akan dilakukan dalam merealisasikan atau mewujudkan visi program studi.

2. Kelemahan: dukungan SDM terutama kualitas dosen masih perlu ditingkatkan untuk memanfaatkan perkembangan IPTEK dan pengembangan keilmuan khususnya yang berhubungan dengan dunia kepariwisataan.

3. Peluang: tersedia dana untuk mengembangkan IPTEK dari institusi nasional maupun internasional untuk mendukung pengembangan profesionalisme tenaga edukatif.

4. Tantangan: persaingan global menuntut setiap tenaga edukatif proaktif memanfaatkan peluang yang ada.

\section{3) Analisis SWOT Lulusan}

Analisis SWOT Kemahasiswaan Prodi Manajemen Tata Hidang

1. Kekuatan: Tingginya minat lulusan SMA yang ingin melanjutkan pendidikan jenjang D3 pada Prodi Manajemen Tata Hidang. Tersedianya beberapa wadah kegiatan untuk menyalurkan minat, bakat dan kreativitas mahasiswa, sehingga dapat meningkatkan kemandirian mahasiswa

baik dalam proses belajar mengajar maupun berbagai kegiatan di luar kampus.

2. Kelemahan: Belum lengkapnya sarana dan prasarana penunjang kegiatan kemahasiswaan. Masih terbatasnya jaringan kemahasiswaan dengan lembaga-

lembaga lain yang dapat bekerjasama. 
3. Peluang: Banyaknya lembaga/perusahaan-perusahaan yang mempercayai dan menyediakan beasiswa bagai mahasiswa yang berprestasi. Tingginya minat pemerintah baik pemerintah daerah maupun provinsi dan pelaku usaha pariwisata untuk melakukan kerjasama dengan Prodi Manajemen Tata Hidang. sehingga akan menanamkan rasa percaya terhadap kualitas dari lulusan Prodi Manajemen Tata Hidang Politeknik Pariwisata Makassar

4. Tantangan: Banyaknya sekolah tinggi atau perguruan tinggi lain yang memiliki program studi pariwisata, menjadi saingan dari alumni Prodi Manajemen Tata Hidang.

\section{4) Analisis SWOT Kurikulum}

1. Kekuatan: Substansi kurikulum Prodi Manajemen Tata Hidang sudah sesuai dengan kebutuhan lapangan kerja, karena dalam penyusunan melibatkan stakeholder dalam bidang kepariwisataan, Kurikulum didesain secara "concurrent" berorientasi pada kebutuhan lapangan, merupakan kombinasi antara pendekatan disiplin ilmu dan pendekatan kompetensi serta bersifat fleksibel. Peninjauan kurikulum dilakukan secara berkala, khusus updating materi perkuliahan dilakukan setiap tahun sejalan dengan perkembangan ilmu pengetahuan dan Teknologi serta tuntutan kebutuhan pasar kerja selain itu IPK rata-rata mahasiswa 3,62.

2. Kelemahan: Implementasi kurikulum bertentangan dengan kompetensi yang harus dimiliki karena dibatasi oleh jumlah sks, waktu, dan jumlah pertemuan sedangkan beban SKS yang harus ditempuh mahasiswa hanya 119 SKS, dan adanya mata kuliah praktek kerja lapangan yang dilaksanakan paling lama 2 bulan yang dirasakan berat berat bagi mahasiswa agar dapat menyelesaikan pendidikan dengan waktu 3 tahun (6 semester), menyebabkan mahasiswa menyelesaikan studi dalam 6 semester.

3. Peluang: mahasiswa telah dibekali kemampuan yang komprehensif dalam ilmu kepariwisataan khususnya mengenai manajemen tata hidang, sehingga mahasiswa dapat berkarya sesuai dengan bidangnya baik bekerja maupun menciptakan lapangan kerja. Penataan sebaran mata kuliah sehingga tidak terjadi penumpukan mata kuliah praktek pada semester tertentu.

4. Tantangan: tuntutan kecenderungan global menuntut kurikulum dengan pembaharuan mutu (benchmarking) terhadap standar yang bertaraf global dan perubahan kebutuhan pasar kerja pariwisata yang relatif cepat, seperti adanya tuntutan sertifikasi dalam kompetensi.

5) Analisis SWOT Pembelajaran

1. Kekuatan: Prodi Manajemen Tata Hidang didukung oleh tenaga pengajar yang memiliki kualifikasi S2 dan S3, serta para pakar dan praktisi dalam 
bidang kepariwisataan. Dosen menyiapkan rencana pengajaran berupa silabi, deskripsi materi perkuliahan, satuan acara perkuliahan (SAP), handout, modul, dan pengadaan fasilitas LCD, sumber bahan ajar, fasilitas internet tersedia di laboratorium, dan sistem penilaian hasil belajar dilakukan dengan transparan. Motivasi belajar dari mahasiswa yang terus meningkat yang dapat dilihat dari peningkatan pencaiapan IPK.

2. Kelemahan: Monitoring perkuliahan baru pada kehadiran dosen, belum pada substansi isi perkuliahan. E-learning belum dikembangkan secara optimal. Belum cukupnya media pembelajaran yang memadai, Tenaga dosen tetap program studi yang masih sangat terbatas.

3. Peluang: Monitoring substansi perkuliahan bisa dilakukan melalui diskusi internal bidang studi, reviu secara sistematis yang dilihat dari komponen kedalaman isi dan kesesuaian dengan tujuan pengajaran, peningkatan kualitas buku bahan ajar. Kesediaan dari narasumber yang berasal dari para pakar dan praktisi bidang kepariwisataan. Terbukanya kerjasama mahasiswa dengan berbagai perusahaan dalam bidang kepariwisataan untuk melakukan observasi, penelitian dan praktek kerja lapangan.

4. Tantangan: Peningkatan teknologi informasi dan komunikasi untuk memudahkan mengakses informasi baru sehubungan dengan peningkatan kualitas pendidikan dan ketepatan studi mahasiswa, evaluasi efektifitas pembelajaran yang akan memacu semua dosen program studi untuk mewujudkan kompetensi yang telah ditetapkan. Adanya sistem pembelajaran yang lebih baik dari perguruan tinggi lain yang bergerak dalam kepariwisataan yang telah terlebih dulu berdiri. Kepuasan stakeholder yang belum dapat dievaluasi secara pasti. Tidak terpenuhinya persyaratan kebutuhan untuk memasuki dunia kerja khususnya dalam bidang kepariwisataan.

\section{SIMPULAN}

Sangat penting untuk membangun jaringan baik dengan instansi swasta maupun pemerintah, ini dimaksudkan sebagai salah satu sosialisasi kemampuan yang dimiliki lulusan Prodi Manajemen Tata Hidang, sehingga instansi terkait tersebut dapat menjadi salah satu instansi yang menjadikan lulusan Prodi Manajemen Tata Hidang sebagai tenaga yang bisa mereka serap. Hendaknya Prodi Manajemen Tata Hidang perlu terus mengoptimalkan jalinan kerja sama dengan stakeholder guna mendapatkan informasi tentang kebutuhan dan tuntutan pasar dunia kerja khususnya yang terkait dengan kompetensi yang diharapkan. 


\section{SARAN DAN REKOMENDASI}

Adanya kompetensi yang relevan maka diharapkan Jurusan Hospitality prodi Manajemen Tata Hidang Politeknik Pariwisata Makassar menghasilkan produk yang baik yang siap kerja. Materi-materi yang sudah sangat relevan dengan kebutuhan kerja harus dipertahankan atau ditingkatkan, karena persaingan di dunia kerja sangat sengit. Berdasarkan penelitian ini menunjukkan bahwa kompetensi yang diajarkan di Jurusan Hospitality prodi Manajemen Tata Hidang Politeknik Pariwisata Makassar sangat relevan dengan kompetensi yang dibutuhkan dunia kerja yang sesuai dengan lapangan kerja lulusan yang meliputi hotel, restauran. Jika untuk mengetahui tingkat relevansi dengan dunia kerja secara sempit yang sesuai karakteristik yang diinginkan maka perlu adanya penelitian lebih lanjut untuk melihat relevansi disetiap karakteristik industri tersebut.

\section{DAFTAR PUSTAKA}

Badollahi, M. Z., \& Almy, m. A. (2019). Xologist Perempuan Di Kota Makassar. PUSAKA (Journal of Tourism, Hospitality, Travel and Business Event), 1(2), 64-74. https://doi.org/10.33649/pusaka.vli2.22

Basusawsta dan irawan. 2005. Manajemen Pemasaran Modern. Yogyakarta: Liberty.

Borang Manajemen Tata Hidang tahun 2017 Politeknik Pariwisata Makassar

Brojonegoro, Bambang dan Jorge Martinez-Vazques. 2005.

Hair,et.al. 2014. Multivariate Data Analysis. New International Edition. New Jersey:Pearson.

Mulyadi.1993. Sistem Akuntansi edisi ketiga. Yogyakarta:YPKN.

Qin Hong and Victor R. Prybutok. 2009. Service quality, customer satisfaction, and behavioral intentions in fast-food restaurant, International Journal of Quality and Service Sciences Vol. 1 No. 1, 2009 pp. 78-95.

Ramanathan Ramakrishnan, Yun Di, and Usha Ramanathan. 2015. Moderating roles of customer characteristics on the link between service factors and satisfaction in a buffet restaurant", Benchmarking: An International Journal Vol. 23 No. 2, 2016 pp. 469-486.

Riza S.Sajad. 2002. Paradigma Baru Pendidikan Tinggi Untuk Menciptakan Sumberdaya Manusia Unggulan. Makassar: Pustaka Kayutangan.

Serdamayanti. 2004. Sumberdaya Manusia dan Produktivitas Kerja. Bandung: Mandar Maju.

Tritjahjo Danny Soesilo dan Setyorini. 2005. Kinerja Alumni BK FISIP UKSW dan Faktor Yang Melatarbelakangi. Satya Widya Vo.I No.I Juni.

Yoeti,Oka.A. 1991. Pengantar Ilmu Pariwisata. Bandung: Angkasa. 
p-ISSN: 2087-3476

e-ISSN: 2541-5700
Pepatuzdu: Media Pendidikan dan Sosial Kemasyarakatan

Vol 16, No. 1 Mei 2020

Zhang Zhang, Zili Zhang, and Rob Law. 2013. Regional effects on customer satisfaction with restaurants, International Journal of Contemporary Hospitality Management Vol. 25 No. 5, 2013 pp. 705-722. 